\title{
ApoB 3'HVR Polymorphism a Genetic Variation in Indian Subcontinent
}

\author{
Faisal Khan ${ }^{1}$, Sudha Talwar ${ }^{1}$, P. Venkataraman ${ }^{2}$, Suhasini Bhatnagar ${ }^{1}$ and Suraksha Agrawal ${ }^{1}$ \\ 1. Department of Medical Genetics, Sanjay Gandhi Postgraduate Institute of Medical Sciences, \\ Raebareli Road, Lucknow 226 014, Uttar Pradesh, India \\ 2. Department of Anthropology, S. V. University, Tirupati 517 502, Andhra Pradesh, India
}

\begin{abstract}
KEY WORDS Apolipoprotien-B; hyper variable region; minisatellites; polymorphism; variation
\end{abstract}

\begin{abstract}
Apo B 3' hyper variable region (Apo B 3', HVR) is a highly polymorphic and hence an informative marker. It could be an ideal candidate to study the genetic heterogeneity among different population groups of Indian subcontinent. It is one of the marker for which numerous population data is available. This makes Apo B 3'HVR an ideal locus for a pilot study to investigate the relationships between different populations and the micro-evolutionary processes leading to their present day distribution. In the present study, we have studied ApoB3'HVR among North Indians and South Indians and have compared these populations on the basis of within group and between group diversity. For this purpose we have selected 600 North Indians and 200 South Indians at random. Total 21 segregating alleles were detected in our population groups. The average observed heterozygosity was quite high (avg.0.753) suggesting high diversity at ApoB'3HVR locus. Low value of average Gst $(0.0005)$ and Fst $(0.035)$ reflects non-significant deviation of heterozygosity between the two groups. On comparing our study populations with central Indian non tribal and tribal groups, it was found that there is relative homogeneity among the three non tribal groups and on computing genetic distances between the four groups, it was observed that tribal significantly differ from the three non-tribal groups. On comparing with other world populations grouped in continental groups, it was clear that greater diversity was observed for Africans followed by the Europeans and Asians. There was relative homogeneity among the continental groups. North Indians and South Indians were found closure to the Asians while non tribal Central Indians clustered with the Eurpeans. We are further testing these observations, by incorporating more realistic demographic models and by using mt-DNA for maternal lineages and Y-chromosome markers for paternal lineages.
\end{abstract}

\section{INTRODUCTION}

Minisatellites- the tandem repeats of se-

Corresponding Author: Prof. Suraksha Agrawal, Department of Medical Genetics, Sanjay Gandhi Post Graduate Institute of Medical Sciences, Raebareli Road, Lucknow 226 014, Uttar Pradesh, India

Phone: 091-522 -440004-8 Ext 2338, 2346, 2347; Fax: 091-522-440973/440017; E-mail: suraksha@sgpgi.ac.in quences ranging from 10-70 base pairs are amongst the most polymorphic markers reported till date (Jaffrey et al. 1985). They exhibit substantial allelic variability in the number of repeat units as a consequence of high rate of germline mutations leading to new allelic states (Jaffrey et al. 1994).

Among the numerous minisatellites known so far, the one located about 75 bp downstream from the 3' end of the Apolipoprotien coding gene is a hyper variable region, designated as ApoB 3' HVR (Knott et al.1986). This locus is highly polymorphic and till now about 23 alleles have been reported. ApoB 3'HVR consists of AT rich core repeat sequence of $15-b p$. Two basic types of 15-bp repeats ( $\mathrm{X}$ and $\mathrm{Y}$ ) have been identified (Huang et al. 1987; Buresi et al. 1996). Presence of high allelic variability at ApoB 3'HVR is due to the complex mutational pattern. Earlier studies have reported that Stepwise Mutational Model (SMM) which reflects gain or loss of one or few repeat units probably due to replication slippage is responsible for creating high polymorphism at ApoB 3'HVR(Jaffrey et al. 1994).

All these features make ApoB 3'HVR, a very useful marker for population studies at genetic level. The availability of numerous population data makes the ApoB 3'HVR an ideal locus for a pilot study to find out the relationships between different populations on the basis of allele frequency distribution and also the micro-evolutionary processes leading to their present day distribution. As ApoB 3'HVR, is a highly polymorphic and informative marker, it could be an ideal marker to study the genetic heterogeneity among different population groups.

India is located at a central position between Europe and Oceania and occupies a centrestage in human evolution. It has served as a major corridor for the dispersal of modern humans that started from Africa about 50ky bp (Cann et al. 2001). The date of entry of humans into India 
remains uncertain. However, human fossils remains date back to late Paleolithic era (55-25 kb bp) and by that time, humans appear to spread to many parts of India (Misra et al. 1992; 2000). ProtAsian and West Eurasian were the next after Africans to have migrated into India (Bamshad et al. 2001). Majumder et al. (1999) have recently provided genetic evidences that a major population expansion took place within India and this was followed by subsequent migration, which resulted in the peopling of South East Asia (Crow et al. 1999).

Moreover, India is a land of enormous geographic, cultural, linguistic and genetic diversity (Bhasin and Walter 2001). With the exception of Africa, India harbors more genetic diversity than other comparable global regions (Majumder et al. 1998). Earlier studies (Roychoudhary et al. 1998; Majumder et al. 1999) indicated that the Indians occupy an intermediaory zone, which has Caucasoid, Negroid, Australoid and Mongoloid elements.

In the present study, we have studied ApoB3'HVR in north Indians and south Indians and have compared these populations on the basis of within group diversity (in terms of heterozygosities, number of alleles, and allele size distribution), between group diversity (in terms

Table 1: Sources of ApoB3' HVR population data

\begin{tabular}{|c|c|c|}
\hline \multicolumn{3}{|c|}{ Africans } \\
\hline 1 & Ewondo (Cameroon) & Destro - Bisol etal. 1994 \\
\hline 2 & Tunisian & Buresi et al.1995 \\
\hline 3 & African Blacks & Hixson et al.1993 \\
\hline 4 & Sotho (African) & Lane et al. 1995 \\
\hline \multicolumn{3}{|c|}{ Europeans } \\
\hline$\overline{1}$ & Germany & Marz et al.1993 \\
\hline 2 & Caucasians (Germany) & Deka et al.1992 \\
\hline 3 & Austria & Friedl et al.1990 \\
\hline 4 & Greece & De Benedicts et al.1994 \\
\hline 5 & Central Italy & Giorgetti et al.1991 \\
\hline 6 & Southern Italy & De Benedicts et al.1994 \\
\hline 7 & Calabria (Italy) & De Benedicts et al.1994 \\
\hline 8 & Bologna (Italy) & Pelloti et al.1994 \\
\hline 9 & Serbia & Alvantic et al.1997 \\
\hline 10 & Sweden & Renges et al.1992 \\
\hline 11 & Mexicans & Latora et al.1994 \\
\hline 12 & Ukraine & Kravchenko et al.1996 \\
\hline 13 & Catolina (Spain) & Gene et al.1995 \\
\hline 14 & Nancy (France) & Chakraboraty et al.1991 \\
\hline 15 & Caucasoid (French) & Boer winkle et al.1989 \\
\hline \multicolumn{3}{|c|}{ Asians } \\
\hline 1 & Han Chinese & Ye et al.1995 \\
\hline 2 & Taiuaan & Evans et al.1993 \\
\hline 3 & United Arab Emirates & $\begin{array}{l}\text { Frossard and Lestringent, } \\
2001\end{array}$ \\
\hline
\end{tabular}

of total genomic diversity and coefficient of gene differentiation) and Wright's F-statistics (in terms of Fixation index). Further, we have compared ApoB3'HVR polymorphism in our studied populations with the Central Indian high caste groups and Tribal populations belonging to India's largest tribal state - Madhya Pradesh (Mastana et al. 2000).

The study is further enlarged by comparing these four groups with other 29 world populations. We have combined the major world populations into three continental groups: Africa, Asia and Europe (Table 1). All the comparisons were done on the basis of allele numbers, heterozygosities and finally by computing genetic distances between these populations.

The purpose of the study was to deduce the informativeness of ApoB 3'HVR among different populations spread over three geographical regions of India and to place these groups in context of other world populations and also to find out whether the allele frequency distribution of ApoB 3'HVR reveals some information about genetic differentiation.

\section{MATERIALSAND METHODS}

\section{Population}

Six hundred unrelated individuals belonging to North India were randomly collected from Uttar Pradesh, and two hundred unrelated individuals belonging to south India were randomly collected from Andhra Pradesh. The ethical committee of the Institute approved the study and blood samples were taken after obtaining informed consent from all the subjects.

\section{Laboratory Analysis}

Genomic DNA was prepared from $2 \mathrm{ml}$ of EDTA blood by high salting out technique (Olerup and Zetterquist 1992). ApoB3'HVR was amplified using primers described by Boerwinkle et al. (1989). The amplified product was then electrophorased on 5\% PAGE and allele scoring was done with the help of ApoB3'HVR allelic ladder and commercial ladder (Invitrogen Ltd.) as shown in Figure 1

\section{Data Analysis}

Allele frequencies were calculated by a simple gene count method (Chakravarti et al. 1984). Cal- 


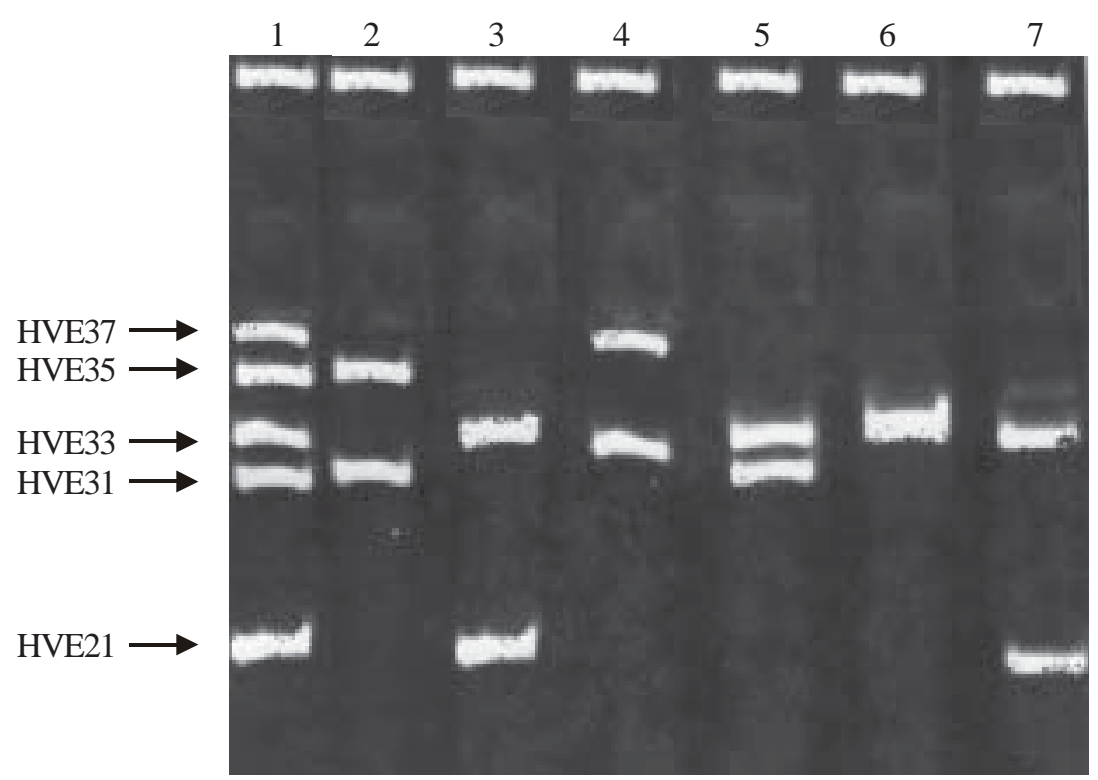

Fig. 1. Different alleles at ApoB3' HVR with sizing ladder.

Lane 1: Allelic ladder for ApoB3' HVR

Lane 2-7: Different samples showing various alleles of ApoB3' HVR

culations of heterozygosity, Ht, Hs, Gst, Fis, and Fst and genetic distances, phylogenetic relationship and Plotting of PC-Plot was done with the help of different software i.e. POPGENE, CERVUS, ARLEQUIN, and PHYLIP.

\section{RESULTS}

\section{Within Group Diversity}

As a first step, we calculated and compared gene diversity in terms of allele number, allele size distribution and heterozygosities in the two study groups. Out of 23 alleles reported in literature only 21 segregating alleles were detected in our population groups. Out of which, 19 alleles were present in North Indian populations while only 14 alleles were found in South Indian populations. Allele frequency distribution at ApoB'3 HVR in these populations is shown in Figure 2. Allele size distribution follow unimodal curve. The mode is centered at $35 \mathrm{HVE}$ among the North Indian populations. The other two alleles with relatively high frequencies are $37 \mathrm{HVE}$ and $33 \mathrm{HVE}$. However, in South Indian samples, the mode was centered at HVE33. The allele frequency distribution shows significant differences at HVE 29,
HVE 31, HVE34, HVE35, HVE36 and HVE41 between two groups. HVE21, HVE25, HVE38, HVE39, HVE45, HVE47 and HVE49 were totally absent from South Indian populations, while HVE30 and HVE32 were not found in North Indian populations. The populations under study were in Hardy Weinberg equilibrium.

The observed heterozygosity was quite high (avg.0.753) suggesting high diversity at ApoB'3HVR locus. South Indians reveals higher heterozygosity (0.790) as compared to the North Indians (0.7170).

\section{Between Group Diversity}

The total genomic diversity $\left(\mathrm{H}_{\mathrm{T}}\right)$ among populations was found to be very high (0.8146) however; most of the genomic diversity was because of diversity between individuals within a subpopulation $\left(\mathrm{H}_{\mathrm{S}}=0.8139\right)$. The percentage of genomic diversity attributable to between populations relative to the total genomic diversity $\left(\mathrm{G}_{\mathrm{ST}}\right)$ was very low (0.0005) despite of the fact that the two groups have shown significant differences at various alleles. Further the low value of the fixation index Fst $(0.035)$ reflects non-significant deviation of heterozygositites between the three 


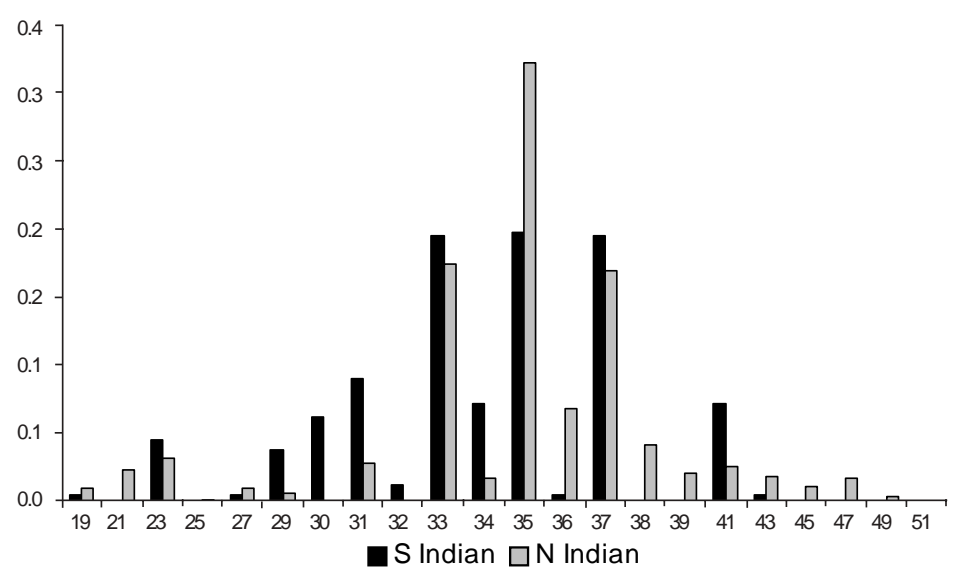

Fig. 2. Allele frequency distribution of ApoB3'HVR in North Indians and South Indians

sub groups (Table 2).

Table 2: Heterozygosities, Ht, Hs, Gst, and Fst, in South and North Indians

\begin{tabular}{lcc}
\hline & South Indians & North Indians \\
\hline No. of Alleles & 14 & 19 \\
$\begin{array}{l}\text { Obs. heterozygosities } \\
\text { Avg. heterozygosity }\end{array}$ & 0.7900 & 0.7170 \\
$\begin{array}{l}\text { Total Genomic diversity (Ht) } \\
\text { Genomic diversity }\end{array}$ & 0.7530 \\
$\quad \begin{array}{l}\text { between population (Hs) } \\
\text { Coefficient of gene } \\
\quad \text { differentiation (Gst) }\end{array}$ & 0.8146 \\
Fixation index (Fst) & 0.0005 \\
\hline
\end{tabular}

\section{Comparison with Central Indians}

When we compared our populations with the Central India higher caste groups and Tribal groups, we observed that only 19 alleles were found in North Indians, 14 in South Indians, 12 in Central Indians and only 13 alleles were reported in the Tribal groups. However, Allele frequency distribution shows that the alleles with higher frequencies are HVE37, HVE35, and HVE33. Interestingly these are almost equally distributed among the four groups. However, HVE 33 was not significantly found in Central Indians. It was also observed that higher alleles (>HVE 37) were found in higher frequency among Central Indians (0.2050), North Indians (0.1390) and Tribal population (0.3193), while lower alleles $(<$ HVE35) were more frequent among South Indians (0.5250) and North Indian (0.3011). When we have computed genetic distances among the four population groups based on Nei's pair wise distance method, we have observed that the three non-
Tribal groups were significantly differ from the Tribal groups (Table 3).

Table 3: Genetic distances between different population groups of India

\begin{tabular}{lcccc}
\hline & $\begin{array}{c}\text { North } \\
\text { Indians }\end{array}$ & $\begin{array}{c}\text { South } \\
\text { Indians }\end{array}$ & $\begin{array}{c}\text { Central } \\
\text { Indians }\end{array}$ & Tribal \\
\hline North Indians & 0.00 & 0.12 & 0.21 & 0.35 \\
South Indians & 0.12 & 0.00 & 0.23 & 0.25 \\
Central Indians & 0.21 & 0.23 & 0.00 & 0.16 \\
Tribals & 0.35 & 0.25 & 0.16 & 0.00 \\
\hline
\end{tabular}

\section{Comparison with Other World Populations}

We have compared the Indian populations with other World populations at continental level i.e. Africa, Asia and Europe. For this purpose we used a four-allele system as described by Alvantic et.al. 1997 in which APOB 3' HVR alleles were categorized into four classes: $\mathrm{HVE}<35$, HVE35, HVE37 and HVE> 37. Allele frequency distribution among different continental groups based on four-allele system is shown in Figure 2. This Analysis clearly indicated greater diversity of Africans followed by the Europeans and Asians. Our population groups reflected much higher heterozygosity (avg. 0.753) as compared to other Asian populations but this variation was lower than Africans (Table 4).

Table 4: Comparison of present study with other continental groups

Avg. heterozygosities

\begin{tabular}{ll}
\hline Africans & 0.887 \\
Europeans & 0.745 \\
Asians & 0.685 \\
Study groups & 0.753
\end{tabular}




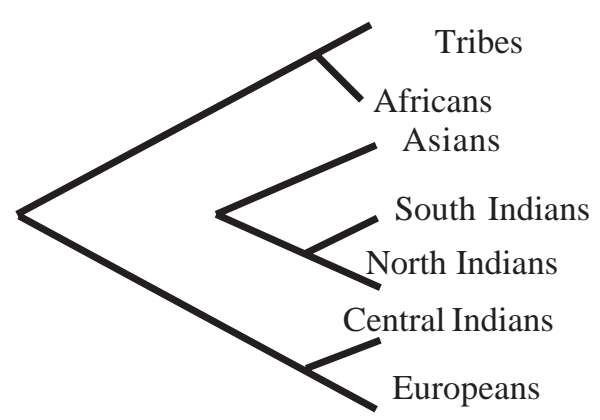

Fig. 3. Neighbor-joining tree constructed on the basis of Nei's pair wise genetic distances.

Further, inter population relationships were analyzed using Nei's pair wise distance, and Reynolds's Fst based distance methods. The distance matrices were used to build Neighbor Joining trees (Fig. 3). It was found that the Tribal populations were very near to the Africans, while the North Indians and South Indians were near to the Asians; however the Central Indians shows similarities with the Europeans.

\section{DISCUSSION}

The allele frequency distribution at ApoB'3 HVR in two Indian population groups suggests that ApoB'3 HVR may be an ideal locus to study the genetic relationships between different ethnic groups of India. The large number of segregating alleles, high value of heterozygosity further supports the utility and informativness of ApoB' 3 HVR in context of Indian populations for carrying out population studies at genetic level, linkage analysis and also for forensic purposes.

The two population groups selected for the present study viz. North Indian and South Indians reveals variation at allele frequency level for some of the alleles when analyzed for ApoB3' HVR. However, the alleles with higher frequencies were equally frequent in both the groups. Further, gene diversity analysis shows that Genomic diversity among populations is very high $(\mathrm{Ht}=0.8143)$, but most of its part is contributed by the diversity between individuals within a sub-population $(\mathrm{Hs}=0.8139)$, while the genomic diversity among the population contributed a negligible amount $(\mathrm{Gst}=0.0005)$. This is also reflected by the Wright's F statistics. $\mathrm{F}_{\mathrm{ST}}$ score over all loci, which was 0.013 implying that there is no significant deviation in the heterozygosities.
Comparison with the Central Indian higher caste groups and tribal populations suggested that non-tribal groups are quit apart from the tribal populations. South Indian and North Indians were found closer to north Indians in comparison to central Indians.

On comparing our populations with other human populations at ApoB3'HVR provides an evidence of a higher genetic diversity in Africans than in non-Africans. Our results are consistent with those of numerous other genetic studies (Destro-Bisol et al. 2000; Jorde et al. 1998), which suggests that the founder non-African population arose as a subset of a large African population (Armor et al. 1996; Shriver et al. 1997). In the case of ApoB3'HVR, it is speculated that the ancestral population was characterized by a high heterozygosity, an extended range of allele size, and a quasi unimodal allele size distribution which is centered on 37HVE. The high level of gene diversity and allele size variance observed in four African population of diverse geographic origin suggests that most of the present day ApoB3' HVR variation was present in the ancestral African populations (Destro-Bisol et al. 2000). When the ancestral population underwent large expansion, it moved out of the continent and inhabited rest of the world; it underwent random genetic drift with a consequent decrease of gene diversity and a reduction of allele size range in the founding populations of non-African groups. Further sampling processes, perhaps bottlenecks that occurred in more recent times could be responsible for the marked reduction in the number of alleles found in some of the Asians, Amerindians, and European populations (DestroBisol et al. 2000; Deka et al. 1992)

This reconstruction suggests that the $37 \mathrm{HVE}$ was predominant in the ancestral population and probably the oldest (Deka et al. 1992). This is suggested by its predominant frequency in almost all the populations examined. In our study populations there was a high frequency of $35 \mathrm{HVE}$ (avg. 0.33) followed by 37HVE (avg. 0.22) and 33HVE (avg.0.19), which is in agreement with other Indian and Asian populations. (Frossard and Lestringent 2001; Aloja et al. 1992; Evans et al. 1993; Ye et al. 1995). It may be deduced from these results that in the Asian continent, especially in the south Asian regions there is relative uniformity in the ApoB3' HVR polymorphism with the presence or absence of certain alleles of low frequency. Moreover, the clustering of different 
populations in UPGMA tree further supports relative homogeneity between continental and / or ethnic groups.

All the inferences drawn based on the present study of ApoB3' HVR polymorphism suggests that Indians have genetic relationships with both proto-Asiatics as well as with the Indo-Europeans. Similar findings have been suggested in recent studies conducted by Bamshad et al. (2001) and Majumder et al. (2001). Our results were in accordance with these studies as both the South Indians and North Indians are near to the Asian populations, while the central Indians are closer to the Europeans. Tribal populations, which constitute about eight percent of the total population of India, are suggested to be the original inhabitants of India who have been migrated from Africa 50 ky bb (Thaper 1996 and Ray 1973) our study also suggests similar observation. Moreover our results support higher genomic diversity in African than non-African groups as well as relative homogeneity among the continental groups at ApoB'3 HVR. However, consideration of other markers like mt-DNA and Y-chromosome markers and incorporation of more realistic demographic models could be of more help in exact dating of the different divergences took place in Indian subcontinent.

\section{REFERENCES}

Alavantic D, Glisic S, Erceg S, Stupar M 1997. Genetic variation at the apoB 3 ' hypervariable region in a Serbian population. Eur J Hum Genet, 5: 333-5.

Aloja E, Dobosz M, Pescarmona M, Moscetti A, Pascali VL 1992. Gene frequencies of APOB alleles in a sample of random Italian individuals (central and southern Italy). In: C Rittner, PM Schneider (Eds.): Advances in Forensic Haemogenetics. Berlin: Springer, 4: 67-9.

Armour JA, Anttinen CA, Maya A 1996. Minisatellite diversity supports a recent African origin of modern humans. Nat Genet, 13: $154-160$.

Bamshad M, Kivisild T, Watkins WS, Dixon ME, Ricker CE, Rao BB, Naidu JM, Raviprasad BV, Reddy PG, Rasanayagam A, Papiha SS, Villems R, Redd AJ, Hammer MF, Nguyen SV, Carroll ML, Batzer MA, Jorde LB 2001. Genetic evidence on the origin of Indian caste populations. Genome Research, 11(6): 994-1004.

Bhasin MK, Walter H 2001. Genetics of Castes and Tribes of India. Delhi: Kamla Raj Enterprises.

Boerwinkle E, Xiong W, Fourest E, Chan L 1989. Rapid typing of tandemly repeated hypervariable loci by the polymerase chain reaction: Application to the apolipoprotein B 3' hypervariable region. Proc Natl Acad Sci USA, 86: 212-216.

Buresi C, Desmarais E, Vigneron S, Ben Rayana C,
Chaabouni H, Roizes G 1995. Polymorphism at VNTR locus 3' to the apolipoprotein gene in a Tunisian population: difference from other ethnic groups. Genet Epidemiol, 12: 381-9.

Buresi C, Desmarais E, Vigneron S, Lamarti H, Smaoui N, Cambien F, Roizes G 1996. Structural analysis of the minisatellite present at the $3^{\prime}$ end of the human apolipoprotein B gene: new definition of the alleles and evolutionary implications. Hum Mol Genet, 5: 61-68.

Cann RL 2001. Genetic clues to dispersal of human popu-lations: Retracing the past from the present. Science, 291: 1742-1748.

Chakraborti R, Fornage M, Gueguen R, Boerwinkle E 1991. Population genetics of hypervariable loci: Analysis of PCR-based VNTR polymorphisms within a population. In: T Burke, G Dolf, AJ Jeffreys, E Wolff (Eds.): DNA Fingerprinting: Approaches and Applications. Basel: Birkhäuser. Pp. 127-43.

Chakravarti A, Li CC, Buetow KH, 1984. Estimation of a marker gene frequency and linkage disequilibrium from conditional marker data. Am J Hum Genet, 36: $177-186$.

Crow TJ 1998. Was the speciation event on the Y chromosome?; Abstracts of Contributions to the Dual Congress 1998. Johannesburg: University of Witwatersrand Medical School. p. 109.

De Benedictis G, Rose G, Falcone E, Semino O, de Luca M, Spadafora P 1994. Population genetics of VNTR markers (TPO and 3' APOB loci) in the Mediterranean area. In: W Bar, A Fiori, U Rossi (Eds.): Advances in Forensic Haemogenetics. Berlin: Springer. 5: 487-9.

Deka R, Chakraborty R, DeCroo S, Rothhammer F, Barton SA, Ferrell RE 1992. Characteristics of polymorphism at a VNTR locus $3^{\prime}$ to the apolipoprotein B gene in five human populations. Am J Hum Genet, 51: $1325-1333$.

Destro-Bisol G, Capelli C, Belledi M., 2000. Inferring Micro evolutionary patterns from allele size frequency distributions of minisatellite loci: A world wide study of ApoB3' hypervariable region polymorphism. Hum Biol, 72: 733-75.

Destro-Bisol G, Presciuttini S, d'Aloja E, Dobosz M, Spedini G, Pascali VL 1994. Genetic variation at the apo B 3' HVR, D2S44, and D7S21 loci in the Ewondo ethnic group of Cameroon. Am J Hum Genet, 55: 168-74.

Evans AE, Zhang W, Moreel JF, Bard JM, Ricard S, Poirier O 1993. Polymorphisms of the apolipoprotein $\mathrm{B}$ and $\mathrm{E}$ genes and their relationship to plasma lipid variables in healthy Chinese men. Hum Genet, 92: 191-7.

Friedl W, Ludwig EH, Paulweber B, Sandhofer F, McCarthy BJ 1990. Hyper variability in a minisatellite $3^{\prime}$ of the apolipoprotein B gene in patients with coronary heart disease compared with normal controls. J Lipid Res, 31: 659-65.

Frossard PM, Lestringant GG 2001. Analysis of an apolipoprotein $\mathrm{B}$ gene 3 ' hypervariable region among Abhu Dhabi emirates. Ann Saudi Med, 19(6): 490-494.

Gene M, Huguet E, Sanchez-Garcia C, Moreno P, Corbella J, Mezquita J 1995. Study of the 3'-apo B minisatellite performed by PCR in the population of Catalonia 
(Northeast Spain). Hum Hered, 45: 70-4.

Giorgetti R, Tagliabracci A, Agostini A, Cingolani M, Ferrara SD 1994. Suitability of PCR methods for forensic investigation: Analysis of the 3' apo B VNTR system in an Italian population sample. Int J Legal Med, 104: 243-6.

Hixson JE, Powers PK, McMahan CA 1993. The human Apolipoprotein B 3' hypervariable region: Detection of eight new alleles and comparisons of allele frequencies in blacks and whites. Hum Genet, 91: 475-9.

Huang LS, Breslow JL 1987. A unique AT- rich hypervariable minisatellite3'Complex gene conversion events in germline mutation in human minisatellites. Nt Genet, 314: 67-73.

Jeffereys AJ, Tamaki K, Macloed A 1994. Complex gene conversion events in germline mutation in human minisatellites. Nature Genetics, 6: 136-145.

Jeffereys AJ, Wilson V, Thein SL 1985. Hypervariable minisatellite regions in Human DNA. Nature, 314: 67-73.

Jorde LB, Bamshad M, Rogers AR 1998. Using mitochondrial DNA and nuclear DNA markers to reconstruct human evolution. Bioassays, 20: 126136.

Knott TJ, Wallis RJ, Pease A 1986. A Hypervariable region 3'to the human apolipoprotien B gene. Nucleic Acids Res, 14: 9215-9216.

Kravchenko SA, Maliarchuk OS, Livshits LA 1996. A population genetic study of the allelic polymorphism in the hypervariable region of the apolipoprotein B gene in the population of different regions of Ukraine (Russian). Tsitologiia $i$ Genetika, 30: 35-41.

Lane AB, Marques I, Jenkins T 1995. ApoB3 VNTR polymorphism in South African populations. In: W Bar, A Fiori, U Rossi (Eds.): Advances in Forensic Heamogenetics. Berlin: Springer. 524-526.

Latorra D, Stern CM, Schanfield MS 1994. Characterization of human AFLP systems apolipoprotein B, phenylalanine hydroxylase, and D1S80. PCR Methods Applic, 3: 351-8.

Majumder PP 1998. People of India: Biological diversity and affinities. Evol Anthrop, 6: 100-110.

Majumder PP, Dey B 2001. Absence of the HIV-1 protective Decr5 allele in most ethnic populations of India. Eur J Hum Genet, 9(10): 234-41.

Majumder PP, Roy, Banerjee S, Chakraborty M, Defy B,
Mukherjee N, Roy M, Thakurta PG, Sil SK 1999. Human specific insertion/deletion polymorphisms in Indian populations and their possible evolutionary implications. Eur J Hum Genet, 7: 435-446.

März W, Ruzicka V, Fisher E, Russ AP, Schneider W, Gross W 1993. Typing of the 3' hypervariable region of the apolipoprotein B gene: Approaches, pitfalls, and applications. Electrophoresis, 14: 169-73.

Mastana SS, Reddy PH, Das MK, Reddy P, Das K 2000. Molecular genetic diversity in 5 populations of Madhya Pradesh, India. Hum Biol, 72(3): 499-510.

Misra VN 1992. Stone age in India: An ecological perspective. Man Environment, 14: 17-64.

Misra VN 2001. Prehistoric human coonization of India. J Bioscnces, 26(Suppl.): 491-531.

Olerup O, Zetterquist H 1992. HLA-DR typing by PCR amplification with sequence-specific primers (PCRSSP) in 2 hours: an alternative to serological DR typing in clinical practice including donor-recipient matching in cadaver transplantation. Tissue Antigens, 39(5): 225-35.

Pelotti S, Degli Esposti P, Pappalardo G 1994. Apo B polymorphism in the district of Bologna (Italy). In: In: W Bar, A Fiori, U Rossi (Eds.): Advances in Forensic Haemogenetics. Berlin: Springer. 5: 547-9.

Ray N, 1973. Nationalism in India. Aligarh: Aligarh Muslim University.

Renges H-H, Peacock R, Dunning AM, Talmud P, Humphries SE 1992. Genetic relationship between the 3 '-VNTR and diallelic apolipoprotein B gene polymorphisms: haplotype analysis in individuals of European and South Asian origin. Ann Hum Genet, 56: 11-33.

Roychoudhury S, Roy S, Dey B, Chakraborty M, Roy M, Roy B, Ramesh A, Prabhakarn N, Usha Rani MV, Vishwanathan H, Mitra M, Sil SK, Majumder PP 2000. Fundamental genomic unity of ethnic India is revealed by analysis of mitochondrial DNA. Curr Sci, 79: 1182-1192.

Shriver MD, Jin E, Ferrel RE 1997. Microsatellite data supports an early population expansion in Africa. Genome Res, 7: 586- 591.

Thapar R 1996. A History of India Vol. 1. Middlesex: Penguin.

Ye P, Chen B, Wang S 1995. The association of polymorphisms at a VNTR locus 3' to the apolipoprotein B gene with coronary heart disease in Chinese population. Chinese Med Sci J, 10: 63-9. 